\title{
Diagnostic Challenge of Peritoneal Tuberculosis in Woman with Ascites
}

\author{
Nenci Siagian", Muhammad Vitanata Arfijanto ${ }^{2 *}$
}

\author{
${ }^{1}$ Department of Internal Medicine, Faculty of Medicine Universitas Airlangga, Surabaya, Indonesia - Dr. Soetomo General \\ Hospital Surabaya, Indonesia \\ ${ }^{2}$ Division of Tropic and Infection, Department of Internal Medicine, Faculty of Medicine Universitas Airlangga, Surabaya, \\ Indonesia - Dr. Soetomo General Hospital Surabaya, Indonesia
}

\section{A R T I C L E I N F O}

\section{Article history:}

Received 13 May 2020

Received in revised form 28 May

2020

Accepted 04 June 2020

Available online 30 June 2020

\section{Keywords:}

Peritoneal tuberculosis,

Ascites,

Adenosin deaminase.

*) Corresponding author:

maftuchah-r@fk.unair.ac.id

\begin{abstract}
A B S T R A C T
Tuberculosis (TB) is a major health global issue including extrapulmonary tuberculosis (EPTB). The one of manifestation of EPTB is peritoneal TB that constitutes $2 \%$ from all cases of pulmonary TB around the world. The diagnosis of peritoneal TB is quite challenging because many cases have symptom that similar to other diseases and those often necessary need further specific examinations such as PCR, culture and radiologic examination. We reported a case report of peritoneal tuberculosis in woman with ascites.
\end{abstract}

\section{Introduction}

Peritoneal TB is a peritoneum or visceral inflamation which is caused by Mycobacterium tuberculosis.1 Most of Peritoneal TB results from pulmonary TB that can happen at any point after primary infection or occurs years or decades later because of the alteration of responsible immune response mechanism. ${ }^{1}$ World Health Organization (WHO) estimates shows that globally there are 8.6 million incident cases of TB which is $80 \%$ are in 22 countries, extrapulmonary tuberculosis (EPTB) constitutes about 15 to $20 \%$ of all cases of TB and more than $50 \%$ of all cases of TB in HIV-positive patients. ${ }^{2}$ Peritoneal tuberculosis constitutes $2 \%$ of all cases of pulmonary TB and $59.8 \%$ of all cases of abdominal TB. ${ }^{1}$ Peritoneal TB is more common in woman than man, $1.5: 1,3 \mathrm{rd}$ and 4 th decade. ${ }^{1}$

Peritoneal TB infection grows slowly and has non specific symptoms so that delay diagnosis and increase the morbidity and mortalitity. ${ }^{1}$ Most of peritoneal TB do not have direct lung involvement and are more likely to have negative sputum smear results. ${ }^{2}$ Ascites is one of common symptom of peritoneal TB that mimic to other disease such as cirrhosis hepatis, autoimmune disease and malignancy. ${ }^{1,3,4}$ So that the diagnosis largely depends on more specific examination. ${ }^{2}$ Therefore, we reported a case report of woman with ascites and other clinical signs of chronic disease and malignancy.

\section{Case report}

A 46-year old female presented with chief complain of swolen abdomen since a month ago. She also complained about intermittent pain at the abdomen. In the last 2 months, she felt tired and weakness easily. It became worst since she couldn't eat because of nausea and vomit since a week ago. She also got fever since a month ago. There is no complain about the loss weight, chronic cough, night sweating. She said thre is no problem with urinate, bowel habbit and menstruation. She has no history of pulmonary TB, diabetes melitus, hypertension, liver and kidney disease before. Physical examination showed that her condition was weak, with blood pressure 100/60 $\mathrm{mmHg}$, pulse 104 beats per minute, respiratory rate 24 times per minute, axillary temperature $37.7^{\circ} \mathrm{C}$, weighed approximately $50 \mathrm{kgs}$, and her consciousness level was alert. Head and neck examination revealed the presence of anemic conjunctiva. Shifting dullness was positive in abdominal examination and pain VAS score was 1-2 on abdominal palpation. Based on history taking and physical examination, we did further laboratorium (Table 1) and imaging examination. The results showed low haemoglobin $(6.9 \mathrm{~g} / \mathrm{dL})$ with hipochromic and micrositer appearance, low albumin level $(2.3 \mathrm{~g} / \mathrm{dL})$, negative hepatitis $\mathrm{B}$ and $\mathrm{C}$ marker, normal urine analysis and chest $\mathrm{X}$-ray (figure1). Based on those datas we planned to examine ascitic fluid and tumor marker. The patient was given PRC and albumin transfusion and symptomatic agent to reduce the complains.

On day 3 , patient had severe vomiting and could not eat 
and drink. From physical examination we found worsen abdominal swelling with meteroism and the pain scale increased. We decided to do decompression with nasogastric tube and lavement to reduce the intraabdominal presure. The abdomen x-ray examination showed there is no signs of bowel obstruction (figure 2). The ascitic fluid analysis showed low serum ascites albumin gradient (SAAG), low total protein, low glucosa, high LDH dan mononuclear cell dominant without malignant cell. The tumor marker showed high Ca-125 level and normal CEA. Based on those datas we assesed the patient with suspect peritoneal TB so we planned to check adenosin deaminase (ADA) test from ascitic fluid and abdominal CT scan to confirm the diagnosis.

Table 1. Laboratory Examination Result

\begin{tabular}{|c|c|c|c|}
\hline Variable & On Admission & Day 3 & Day 6 \\
\hline \multicolumn{4}{|l|}{ Blood } \\
\hline Haemoglobin & $6.9 \mathrm{~g} / \mathrm{dL}$ & $10.6 \mathrm{~g} / \mathrm{dL}$ & \\
\hline WBC & $3790 / \mu \mathrm{L}$ & $4800 / \mu \mathrm{L}$ & \\
\hline Platelet & $352000 / \mu \mathrm{L}$ & $289000 / \mu \mathrm{L}$ & \\
\hline Neutrophil & $76.7 \%$ & $77.8 \%$ & \\
\hline Lymphocyte & $7.7 \%$ & $7.5 \%$ & \\
\hline Erytrocyte Sedimentation Rate & $60 \mathrm{~mm} / \mathrm{h}$ & & \\
\hline Blood glucose & $128 \mathrm{mg} / \mathrm{dL}$ & & \\
\hline SGOT & $46.0 \mathrm{U} / \mathrm{L}$ & & \\
\hline SGPT & $25.0 \mathrm{U} / \mathrm{L}$ & & \\
\hline Ureum & $11.0 \mathrm{mg} / \mathrm{dL}$ & $35.0 \mathrm{mg} / \mathrm{dL}$ & $17 \mathrm{mg} / \mathrm{dL}$ \\
\hline Serum Creatinin & $0,85 \mathrm{mg} / \mathrm{dL}$ & $1.2 \mathrm{mg} / \mathrm{dL}$ & $0.9 \mathrm{mg} / \mathrm{dL}$ \\
\hline Albumin & $2.3 \mathrm{~g} / \mathrm{dL}$ & $2.7 \mathrm{~g} / \mathrm{dL}$ & \\
\hline Sodium & $133 \mathrm{mmol} / \mathrm{L}$ & $139 \mathrm{mmol} / \mathrm{L}$ & \\
\hline Potassium & $3.7 \mathrm{mmol} / \mathrm{L}$ & $4.5 \mathrm{mmol} / \mathrm{L}$ & \\
\hline Chloride & $97 \mathrm{mmol} / \mathrm{L}$ & $100 \mathrm{mmol} / \mathrm{L}$ & \\
\hline $\mathrm{HbsAg}$ & Non reactive & & \\
\hline Anti HCV & Non reactive & & \\
\hline \multicolumn{4}{|l|}{ Ascitic Fluid Analysis } \\
\hline WBC-BF & $0.22 \times 103 / \mu \mathrm{L}$ & & \\
\hline RBC-BF & $0.002 \times 103 / \mu \mathrm{L}$ & & \\
\hline Total Protein & $5.1 \mathrm{~g} / \mathrm{dL}$ & & \\
\hline Glucose & $75 \mathrm{mg} / \mathrm{dL}$ & & \\
\hline $\mathrm{LDH}$ & $263 \mu \mathrm{L}$ & & \\
\hline $\mathrm{MN} \%$ & $86.5 \%$ & & \\
\hline PMN\% & $13.5 \%$ & & \\
\hline \multicolumn{4}{|l|}{ Urine analysis } \\
\hline Blood & Negative & & \\
\hline Leucocyte & ++ & & \\
\hline Nitrit & Negative & & \\
\hline Protein & Negative & & \\
\hline Glucose & Negative & & \\
\hline Ca-125 & & $143.3 \mathrm{U} / \mathrm{mL}$ & \\
\hline Cytology & & $\begin{array}{l}\text { Mononuclear cell dominant without } \\
\text { malignant cell }\end{array}$ & \\
\hline
\end{tabular}

On day 5, the complain of vomiting became regressed and she could eat porridge. From physical examination the pain scale decreased. The result of ADA test was high (51.4 U/L ,with cut off $30 \mathrm{U} / \mathrm{L}$ ) and abdominal CT scan showed lobulated fluid, extraluminal at abdominal and pelvic cavum, thickening bowel wall with contrast enhancement (figure 3). Based on those findimgs we diagnosed the patient with peritoneal TB. The patient was given first category of anti TB drug based on her weight for 9-12 months (2HRZE/10HR) and discharged 2 days later. The sign and symptoms revealed after six months of treatment. 


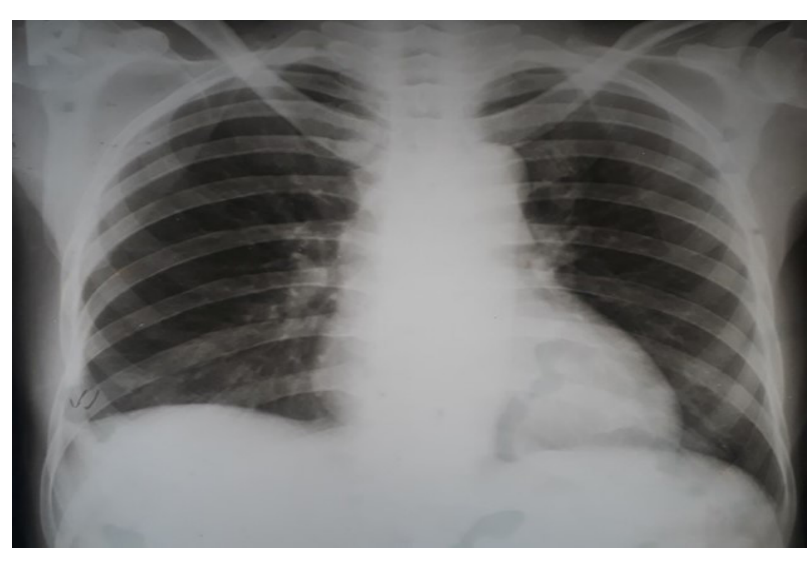

Figure 1. Chest x-ray of patient showed no sign of pulmonary tuberculosis

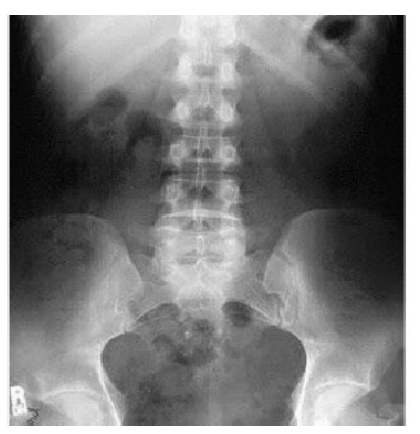

a

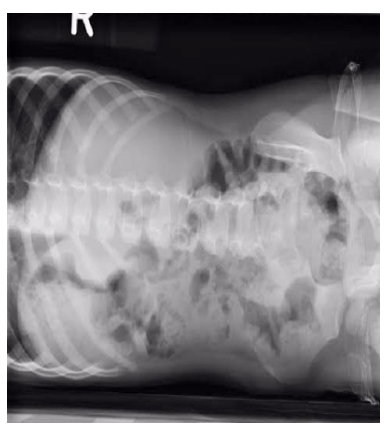

b
Figure 2. Abdominal x-ray: a.) supine and b.) left lateral decubitus showed no sign ofbowel obstruction
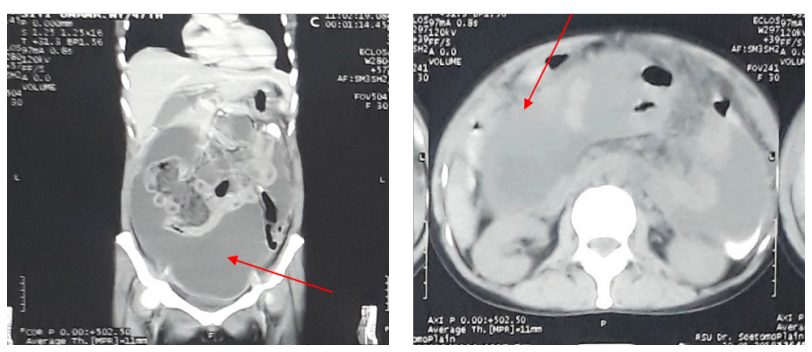

Figure 3. Abdominal CT scan showed extraluminal and loculated free fluid intensity, with contrast enhancement at abdomen cavity and pelvic cavity (arrow)

\section{Discussion}

Peritoneal TB is one of kind of abdominal TB that affect the parietal or visceral peritoneum. ${ }^{1}$ Peritoneal TB results from the hematogenous and lymphatic spread of primary infection of M. tuberculosis bacilli. ${ }^{2}$ Although this can happen at any point after primary infection, it most commonly occurs years or decades later, because the reactivation of latent focus of TB at peritoneum. That's why patients with peritoneal TB do not have direct lung involvement. $^{2}$ There are two conditions of peritoneal TB, acute and chronic. ${ }^{4}$ The acute condition shows acute abdomen signs and symptoms with or without ascites. ${ }^{4}$ The chronic condition has 3 types: (1). Wet type; patient comes with ascites, anorexia and weight loss (2) Encysted (loculated) type; patient comes with abdominal swelling at certain location (3) Fibrous type; patient comes with sign and symptom of ileus due to bowel attachment (chest board phenomen).4 Abdominal swelling (65-100\%), abdominal pain $(36-93 \%),{ }^{4.5}$ anaemia $(48-68 \%)$ and ascites on physical examination $(51-100 \%)^{5}$ are common clinical presentation of peritoneal TB and can be found in other diseases such as malignancy, autoimune and cirrhosis hepatis. ${ }^{1,3,4}$ On day 3 , the patient had severe vomit likely because of the gastric outlet impairment due to ascites. But we have to always consider about ileus obstruction as a complication which could be happen anytime in this case.

Analysis and citology of ascitic fluid are very helpful to distinguish the type of ascites. The SAAG value less than $1.1 \mathrm{~g} / \mathrm{dL}$ showed that the asitic is non cirrhotic ascites. The glukosa ascites serum ratio less than 0.96 and total protein more than $2.5 \mathrm{~g} / \mathrm{dL}$ may reffer to tuberculosis infection. However those values have low sensitivity for diagnosis of peritoneal TB. ${ }^{1,4,6}$ The gold standard of peritoneal TB diagnosis is $\mathrm{M}$. tuberculosis found in suspected specimen which is ascitic fluid. ${ }^{1,7}$ The studies reported that the sensitivity of zeihl neissen stain is $0-3 \%$, the sensitivity of PCR examination is less than 5\% and the sensitivity culture of M. tuberculosis is $35-50 \% .{ }^{8,9}$ But the studies reported that ADA test has sensitivity and spesificity over than $90 \%$ (cut off 30-45U/L).10 ADA value is increased in tuberculous ascitic fluid because of the stimulation of $\mathrm{T}$ cells by the mycobacterial antigens. ADA activity in the peritoneal fluid has been proved to be a simple and reliable method for early diagnosis of tuberculous peritonitis. 10 The tumor marker Ca-125 can be higher than normal in peritoneal TB so that $\mathrm{Ca}-125$ can be used for treatment evaluation. ${ }^{11}$

Ultrasonography (USG) is a routine examination for non cirrotic ascites but sometimes the result is less representative. ${ }^{12}$ Abdominal CT scan has high diagnostic value for peritoneal TB such as loculated fluid in abdomen cavum (70-90\%) or thickening peritoneal wall and contrast enhancement (70\%). ${ }^{13}$ Laparoscopy is an invasive procedure and increase the risk of perforation however it performed in peritoneal TB with bowel adhesion that can lead to intestinal obstruction. ${ }^{14}$

The guideline of therapy of peritoneal TB in Indonesia is based on Ministry of Health regulator (PERMENKES) number 67 2016. ${ }^{15}$ Peritoneal TB is treated with anti tuberculosis drug first category for 9-12 months. The regimen consists of Rifampin 10mg/kg, Isoniazid $5 \mathrm{mg} / \mathrm{kg}$, Pyrazinamide $15 \mathrm{mg} / \mathrm{kgBB}$ and Ethambutol $15 \mathrm{mg} / \mathrm{kg}$ for 2 months and continue with Rifampicin $10 \mathrm{mg} / \mathrm{kgBB} 3 \mathrm{x} /$ week and Isoniazide $5 \mathrm{mg} / \mathrm{KgBB} 3 \mathrm{x} /$ week for $7-10$ months. ${ }^{15}$ The surgery procedure is needed for peritoneal TB with symptom of bowel obstruction, perforation and peritonitis. Surgery sometimes conducted if conservative treatment is failed. ${ }^{14}$ The prognosis of peritoneal TB is good as long as the patient gets adequate anti tuberculosis drug. ${ }^{1}$

\section{Conclusion}

The diagnosis of extrapulmonary $\mathrm{TB}$ is still quite challenging in most of cases such as peritoneal TB. Peritoneal TB may shows ascites that similar to other disease like cirrosis hepatic or malignancy. It needs more spesific examination which is taken from suspicious location to find the $M$. tuberculosis to confirm the diagnosis. However in peritoneal TB, ADA test has higher sensitvity and specifity than zeihl neissen staning, GeneXpert and culture. The conservative therapy with anti tuberculosis drug is the main therapy for peritoneal TB. 
However surgery procedure will be need if there is sign of acute abdomen due to bowel obstruction.

\section{Conflict of Interest}

The author stated there is no conflict of interest

\section{References}

1. Zain HL. Tuberkulosis Peritoneal. In: Buku Ajar Ilmu Penyakit Dalam Fakultas Kedokteran Universitas Indonesia. 2015

2. Purohit M, Mustafa T. Laboratory diagnosis of extra-pulmonary tuberculosis (EPTB) in resource-constrained setting: State of the art, challenges and the need. J Clin Diagnostic Res. 2015

3. Raviglione CM. Mycobacterial Diseases. in: Fauci AS, Braunwald E, Isselbacher KJ, Wilson JD, Martin JB, Kasper DL, et al., editors. Harrison's Principles of Internal Medicine. 19th ed. New York: McGraw-Hill;2015

4.. Karanikas M, Porpodis K, Zarogoulidis P, Mitrakas A, Touzopoulos $\mathrm{P}$, Lyratzopoulos N, et al. Tuberculosis in the Peritoneum: Not too Rare After All. Case Report Gastroeneterology. 2012

5. Rathi P, Gambhire P. Abdominal Tuberculosis. J Assoc Physicians India. 2016

6. Tsao GG. Ascites. In: Sherlock's Disease of the Liver and Biliary System. 13th ed, Oxford: John Wiley\&Sons Ltd; 2017
7. Chaudhuri A. Recent changes in technical and operational guidelines for tuberculosis control programme in India - 2016: A paradigm shift in tuberculosis control. J Assoc Chest Physicians. 2017

8. Mehta PK, Raj A, Singh N, Khuller GK. Diagnosis of extrapulmonary tuberculosis by PCR. FEMS Immunol Med Microbiol. 2012

9. Tewari M, Sahoo SP, Shukla HS. Abdominal Tuberculosis. In: Tuberculosis, 2nd ed, India. Jaypee Brothers Medical Publisher (p) Ltd; 2009

10. Lakkana Boonyagars SK. Use of Adenosine Deaminase for the Diagnosis of Tuberculosis: A Review. J INFECT DIS ANTIMICROB AGENTS. 2010;

11. Mas MR, Comert B, Saglamkaya U, Yamanel L, Kuzhan O, Ateskan $\mathrm{U}$, et al. CA-125; a new marker for diagnosis and follow-up of patients with tuberculous peritonitis. Dig Liver Dis. 2000

12. Rosado E, Penha D, Paixao P. Abdominal Tuberculosis - Imaging Findings. European Society of Radiology. ECR journal. 2013;

13. Rocha EL da, Pedrassa BC, Bormann RL, Kierszenbaum ML, Torres LR, D'Ippolito G. Abdominal tuberculosis: a radiological review with emphasis on computed tomography and magnetic resonance imaging findings. Radiol Bras. 2015

14. Wyers SG, Matthews JB. Surgical Peritonitis and Other Diseases of the Peritoneum, Mesentery, Omentum, and Diaphragm. In: Sleisenger and Fordtran's Gastrointestinal and Liver Disease. 2010

15. Peraturan Menteri Kesehatan (PERMENKES) Republik Indonesia Nomor 67. 2016. 